\title{
Alteration of protein localization and intracellular calcium content due to connexin26 D50A and A88V mutations
}

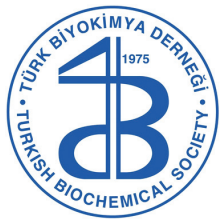
D50A ve A88V mutasyonlarına bağlı connexin 26 protein lokalizasyonunun ve hücre içi kalsiyum miktarının değişsimi

DOI 10.1515/tjb-2016-0292

Received November 30, 2015; accepted July 13, 2016

\begin{abstract}
Introduction: Connexins (Cx) play essential roles in cellular homeostasis by forming gap junctions and non-junctional hemichannels. In vitro characterization of Cx26 mutations causing keratitis-ichthyosis-deafness (KID) syndrome, were shown to form leaky hemichannels. The molecular/ cellular mechanisms affected by aberrant hemichannels have recently been elucidated. Here, we further wanted to characterize Cx26 KID syndrome mutations, D50A and $\mathrm{A} 88 \mathrm{~V}$, which were shown to form aberrant hemichannels and remained unaddressed in the literature.

Methods: Neurobiotin uptake assay in HeLa and N2A cells transfected with Cx26-WT, D50A or A88V verified the presence of aberrant hemichannels and immunofluorescent staining with fluorescent microscopy determined cellular localization of Cx26. Finally, intracellular calcium content was examined by using calcium indicator, Fluo-3AM, and flow cytometer.

Results: Cx26-D50A and A88V mutations prevented the formation of gap junction plaques at cell-cell appositions and mutant proteins were observed to localize to the Golgi apparatus. Further, comparison of intracellular calcium content showed an increase in calcium amount in cells containing Cx26-D50A and A88V relative to Cx26-WT.
\end{abstract}

*Corresponding author: Gülistan Meşe, PhD, Department of Molecular Biology and Genetics Rm: D206, Izmir Institute of Technology, Urla 35430, Izmir, Turkey, Phone: +90 2327507312 , Fax: + 902327507303 , e-mail: gulistanmese@iyte.edu.tr Hande Aypek: Department of Molecular Biology and Genetics, Izmir Institute of Technology, Urla, Izmir, Turkey
Conclusion: Retention of Cx26 in the Golgi apparatus and alteration in the intracellular calcium content due to KID syndrome mutations may influence various cellular processes that might contribute to development of epidermal phenotypes.

Keywords: Connexin26; Mutations; Keratitis-ichthyosisdeafness (KID) syndrome; Intracellular calcium; Golgi apparatus.

\section{Özet}

Giriş: Connexin molekülleri $(\mathrm{Cx})$ kurdukları hücrelerarası kanallar ve hücrelerarası olmayan yarı kanallar sayesinde hücre yaşamını dengelemede önemli roller üstlenirler. İn vitro analizlerle keratitis-ichthyosis-deafness (KID) sendromuyla ilişkili Cx26 mutasyonlarının düzgün kapanamayan yarı kanalların oluşmasına sebep oldukları gösterilmiştir. Bu tip anormal çalışan yarı kanalların etkilediği moleküler / hücresel mekanizmalar son zamanlarda araştırılmaya başlanmıştır. Bu çalışmada amacımız, daha önce yarı kanallar yaptıkları gösterilen Cx26'da oluşan KID sendromu mutasyonlarından D50A ve A88V'nin hücre biyolojisinde yaptığı değişiklikleri incelemektir.

Yöntemler: Cx26-WT, D50Y ve A88V ile transfekte edilen HeLa ve N2A hücrelerinde neurobiotin boya alım deneyleriyle anormal yarı kanalların varlığ teyit edilmiş ve floresan mikroskop ve immunoboyamasıyla Cx26'nın hücre içi lokalizayonu belirlenmiştir. Son olarak, kalsiyum belirteci, Fluo-3AM ve akış sitometresi kullanarak hücre içi kalsiyum içeriği belirlenmiştir.

Bulgular: Cx26-D50A ve A88V mutasyonları hücreler aras1 kanalların oluşumunu engellemiş, aynı zamanda mutant proteinler hücrede Golgi aygıtında lokalize olmuşlardır. 
Ek olarak normal Cx26 ile kıyaslandığında Cx26-D50A ve A88V bulunduran hücrelerde hücre içerisindeki kalsiyum miktarının arttığı tespit edilmiştir.

Sonuç: KID hastalarında görülen epidermal bozuklukların oluşmasında, mutant Cx26 proteinlerinin Golgi aparatında tutularak ve anormal yarı kanal oluşturup hücresel kalsiyum dengesini bozarak çeşitli hücre fonksiyonlarında neden olduğu değişimlerin rol oynayabileceği düşünülmektedir.

Anahtar kelimeler: Connexin26; Mutasyon; Keratitisichthyosis-deafness (KID) sendromu; Hücresel kalsiyum; Golgi aygit1.

\section{Introduction}

Connexins (Cx) are one of the building blocks of gap junctions in vertebrates. At least 21 connexin isoforms have been identified in the human genome which are expressed throughout the body in a cell/tissue type and developmental stage-specific manner [1, 2]. Gap junctions mediate various cellular processes including both the delivery of nutrients and removal of waste from avascular organs, electrical and metabolic coupling of cells, cell growth, proliferation, and differentiation by allowing the passage of molecules between adjacent cells [3-5]. In addition to the formation of intercellular channels that couple adjacent cells, connexins also function as nonjunctional hemichannels that can facilitate the exchange of molecules across the plasma membrane and regulate cellular/tissue homeostasis [6]. Under physiological conditions, hemichannels are closed to prevent the leakage and uncontrolled uptake of molecules across the plasma membrane [7-9]. On the other hand, external insults, stress or mutations in connexin genes can disrupt proper sealing of hemichannels and negatively affect cellular physiology [10-15].

The importance of connexin mediated cellular communication for human physiology is better understood with characterization of various human disorders and their associations to mutations in several connexin isoforms, such as cataract ( $\mathrm{Cx} 46, \mathrm{Cx} 50)$, hearing loss, skin disorders (Cx26, Cx30) and hereditary peripheral neuropathy (Cx32) [3, 16-19]. In vitro characterization of disease-associated connexin mutations showed that mutations affect various processes in connexin biogenesis and function including but not limited to the generation of truncated proteins, altered trafficking, prevention of gap junction channel formation and function as well as altered hemichannel activities [20]. For example, all of the characterized Cx26 mutations associated with keratitis-ichthyosis-deafness (KID) syndrome were shown to lead to the formation of aberrant hemichannels [13-15, 21]. Therefore, the formation of abnormal hemichannels due to $\mathrm{Cx} 26$ mutations was suggested to be the underlying cause of epidermal anomalies observed in KID syndrome patients. In this respect, mutant $\mathrm{Cx} 26$ hemichannels are thought to interfere with keratinocyte homeostasis by releasing signaling molecules such as $\mathrm{Ca}^{2+}$ and ATP into the extracellular environment as a paracrine element and alter the epidermal physiology [22, 23]. However, the exact mechanisms of how aberrant hemichannels influence keratinocyte homeostasis and generate skin phenotypes of KID syndrome are not completely known. One of the components important for the epidermis is the maintenance of calcium homeostasis as abnormal calcium signaling was implicated with several human disorders [24, 25]. In that respect, here we aimed to determine alterations in the $\mathrm{Cx} 26$ biogenesis and the intracellular calcium content caused by KID syndrome associated Cx26-D50A and $\mathrm{A} 88 \mathrm{~V}$ mutations, which were previously shown to cause elevated membrane currents in Xenopus oocytes and HeLa cells [26].

\section{Materials and methods}

\section{Site-directed mutagenesis to generate Cx26 mutant clones}

Human Cx26 WT (wild-type) cDNA was used to generate Cx26-D50A and A88V missense point mutations by using site-directed mutagenesis. After cloning of PCR products into pBlueScript cloning vector, location and insertion of mutations were verified by sequencing (Macrogen Europe, The Netherlands). Then, Cx26-WT, D50A and A88V cDNAs were subcloned into pIRES2EGFP2 and pCS2+ mammalian expression vectors.

\section{Cell culture}

HeLa and neuro-2A (N2A) (ATCC, USA) were maintained in Dulbecco's Modified Eagle Medium (DMEM, Thermo Scientific HyClone, USA) supplemented with $10 \%$ fetal bovine serum (FBS) (Biological Industries, Israel) and $1 \%$ penicillin/streptomycin (GIBCO, USA) in a humidified chamber with $5 \% \mathrm{CO}_{2}$ and $37^{\circ} \mathrm{C}$. Cells were plated in 6 well plates for transfection with Lipofectamine 2000 reagent (Invitrogen, USA) on the following day with 1:2 DNA to 
Lipofectamine 2000 ratio following the manufacturer's protocol. $3.2 \mathrm{mM} \mathrm{CaCI}_{2}$ was added in medium to close prospective hemichannels and cells were used within 24-36 h after transfection.

\section{Neurobiotin dye uptake assay}

N2A cells transfected with pIRES2EGFP2 clones were used for fluorescent dye uptake assays with neurobiotin (NB, $287 \mathrm{Da},+1$ charge, Vector Labs, USA). Twenty four hours after transfection, cells were washed with PBS and incubated with $\mathrm{Ca}^{2+}$ free medium for $20 \mathrm{~min}$ at $37^{\circ} \mathrm{C}$. Cells were then incubated with $0.5 \mathrm{mg} / \mathrm{mL} \mathrm{NB}$ for $20 \mathrm{~min}$ and were washed with PBS containing $3.2 \mathrm{mM} \mathrm{CaCl}_{2}$ three times for $10 \mathrm{~min}$. After fixation of cells with 4\% paraformaldehyde (PFA) for $20 \mathrm{~min}$ at room temperature (RT), cells were permeabilized with $0.1 \%$ Triton-X 100 for $10 \mathrm{~min}$, blocked with 3\% BSA-0.1\% TritonX-100 for $15 \mathrm{~min}$ and then were incubated with tetra-methyl rhodamine isothiocyanate (TRIT-C) conjugated streptavidin (1:1000 dilution, Pierce, USA) for 30 min at RT in dark. Images were acquired with a fluorescence microscope (IX71, Olympus, Japan) using the same exposure times for all conditions. Image analysis for signal intensity was performed with ImageJ (NIH, USA) program. Background subtraction was applied to all images before thresholding and signal intensities of fluorescence within cells were determined.

\section{Immunofluorescent staining}

HeLa cells $\left(2.5 \times 10^{5}\right)$ were cultured on glass coverslips in 6 well plates and transfected with pCS2+ clones. After washing with PBS, cells were fixed with $4 \%$ PFA for 20 min, permeabilized with $0.1 \%$ Triton-X 100 for 15 min and blocked with 3\% bovine serum albumin (BSA) for $1 \mathrm{~h}$ at room temperature (RT). A 1:500 dilution of a polyclonal rabbit anti-Cx26 antibody (Invitrogen, USA) was applied for $1 \mathrm{~h}$ at RT followed by an incubation with $1: 200$ dilution of Alexa555-conjugated goat anti-rabbit antibody (Invitrogen, USA), 1:200 dilution of Alexa Fluor 488 conjugated Phalloidin (Invitrogen, USA) and $1 \mu \mathrm{M}$ DAPI for $45 \mathrm{~min}$ at RT in dark. Antibodies and DAPI was removed by PBS wash and coverslips were dipped in distilled water, dried and mounted on glass slides. Staining was verified under fluorescence microscope (IX83, Olympus, Japan) with $\times 40$ objective and images were taken with a CCD digital camera [27].

For co-immunofluorescent staining of golgin-97 and $\mathrm{Cx} 26,1 \mathrm{~h}$ incubation at room temperature with primary antibodies [rabbit anti-Cx26 antibody $(1: 500)$ and mouse anti-golgin-97 (1:1000) (Invitrogen, USA)] was followed by the application of secondary antibodies [Alexa555-conjugated goat anti-rabbit and Alexa488-conjugated goat anti-mouse secondary antibody $(1: 200$, Invitrogen, USA)] and $1 \mu \mathrm{M}$ DAPI for $45 \mathrm{~min}$ at RT in dark. After washing with PBS, coverslips were dipped in distilled water, dried and mounted on glass slides. Staining was verified under fluorescence microscope (IX83, Olympus, Japan) with $\times 40$ objective and images were taken with a CCD digital camera.

\section{Measurement of intracellular calcium levels}

Intracellular calcium content in $\mathrm{N} 2 \mathrm{~A}$ cells $\left(5 \times 10^{5}\right)$ transfected with pCS2+ clones was determined by using Fluo$3 \mathrm{AM} \mathrm{Ca}^{2+}$ indicator (Invitrogen, USA) and flow cytometry [23]. After washing cells with $\mathrm{Ca}^{2+}$ free $\mathrm{PBS}$ twice for $5 \mathrm{~min}$, cells were incubated with $5 \mu \mathrm{M}$ Fluo-3AM at $37^{\circ} \mathrm{C}$ for $30 \mathrm{~min}$. Then, cells were washed with PBS, trypsinized, pelleted and resuspended in $300 \mu \mathrm{L}$ Hank's Balanced Salt Solution (HBSS) [28] and analyzed with FACSCANTO (BD Biosciences, USA).

\section{Statistical analysis}

All results were expressed as mean ( \pm standard deviation). Groups were compared using ANOVA followed by Student-Newman-Keuls post-hoc comparison analysis. Statistical significance was considered for $\mathrm{p}<0.05$.

\section{Results}

\section{Verification of the ability of Cx26-D50A and A88V mutations to form aberrant hemichannels}

Cx26-D50A and A88V mutations were previously shown to cause elevated membrane currents in cRNA injected Xenopus oocytes and in HeLa cells, suggesting the presence of active hemichannels [26]. We wanted to confirm if these mutations were also able to facilitate the uptake of fluorescent dyes in transfected N2A cells (Figure 1). In sample images, neurobiotin fluorescent intensities were observed to increase in cells with Cx26-WT relative to the negative control, pIRES2EGFP2 transfected cells. Further, cells with Cx26-D50A and A88V had higher neurobiotin 
A
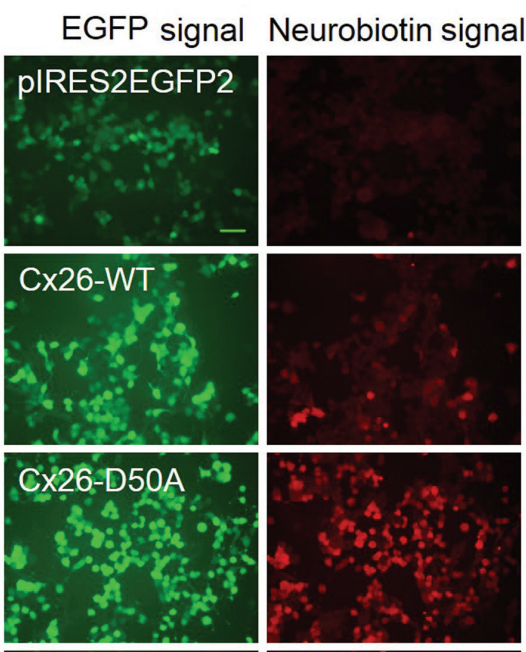

B
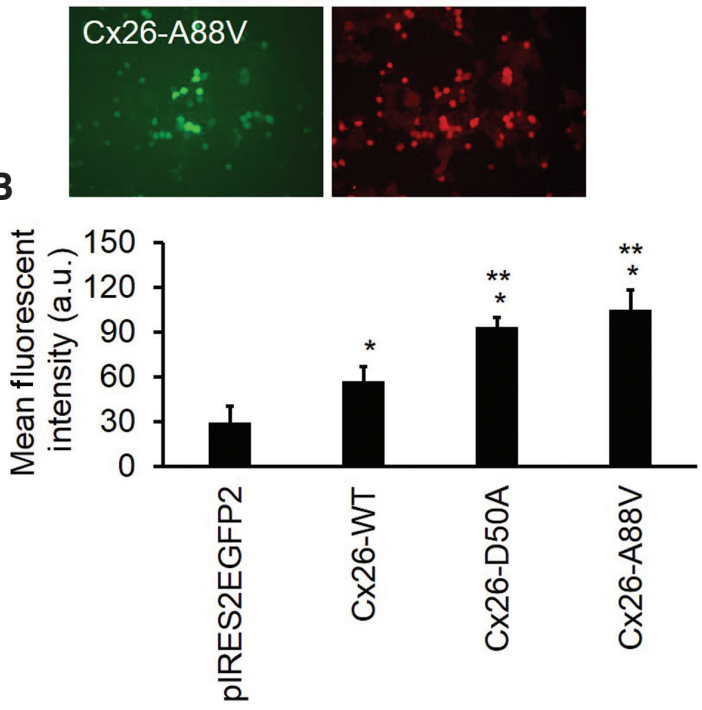

Figure 1: Aberrant hemichannel activities of Cx26-D50A and A88V. (A) Representative images from neurobiotin uptake assays. pIRES2EGFP2 transfected cells were used as a negative control. Green is for GFP expression and red is for neurobiotin signal. Scale bar $90 \mu \mathrm{m}$. (B) Comparison of fluorescent dye intensities in transfected cells. Cx26-D50A and A88V were compared with both negative control pIRES2EGFP2 and Cx26-WT ( $p$-value * $<0.001$ comparison between pIRES2EGFP2 and CX26-WT, D50Y, A88V; $p^{\star \star}<0.001$ comparison between Cx26-WT and mutants D50Y and A88V).

signals than cells with Cx26-WT (Figure 1A). Fluorescent signal intensity analysis from at least 15 images from three different experiments suggested that the fluorescent intensity in cells transfected with Cx26-WT increased by 2-fold $(\mathrm{p}<0.001)$ compared to cells with pIRES2EGFP2 (Figure 1B). Further, Cx26-D50A and Cx26-A88V resulted in 3.2 and 3.6-fold $(\mathrm{p}<0.001)$ increase in neurobiotin uptake relative to pIRES2EGFP2 cells and 1.6 and 1.8fold ( $\mathrm{p}<0.001)$ increase compared to cells with Cx26-WT, respectively. Neurobiotin uptake assay confirmed the ability of Cx26-D50A and A88V mutations to form aberrant hemichannels and also showed that these hemichannels allow the passage of larger molecules than ions across the plasma membrane [26].

\section{Effect of Cx26-D50A and A88V mutations on the $\mathrm{C} \times 26$ protein biosynthesis and trafficking}

To examine the effects of KID syndrome associated Cx26D50A and A88V mutations on protein biosynthesis and trafficking, HeLa cells transiently transfected with pIRES2EGFP2 Cx26-WT, D50A and A88V constructs were used for immunofluorescent staining (Figure 2). Cells expressing Cx26-WT, D50A and A88V constructs were able to synthesize $\mathrm{Cx} 26$ proteins as observed by $\mathrm{Cx} 26$ signals in representative images in Figure 2 (red signals). Furthermore, Cx26-WT expressing cells had gap junction plaques at the cell-to-cell contact sites between adjacent cells (Figure 2A, white arrows). On the other hand, no gap junctional plaques were observed between neighboring cells transfected with either Cx26-D50A or A88V mutant constructs (Figure 2A, white arrows), suggesting that they impaired the formation of gap junction channels between adjacent cells as also shown by Mhaske et al. [26].

To examine whether these mutations caused defects in Cx26 protein trafficking, co-immunostaining of Cx26 and golgin-97, a Golgi apparatus marker, was performed (Figure 2B). There was no co-localization between Cx26 (red signal) and golgin-97 (green) in Cx26-WT expressing cells. In contrast, Cx26-D50A and A88V mutant proteins were detected to extensively overlap with golgin-97 in transfected cells as observed by yellow signals in transfected cells (Figure 2B). These suggested that a fraction of proteins retained in the Golgi apparatus while others formed hemichannels on the plasma membrane.

\section{Effect of Cx26-D50A and A88V mutations on intracellular calcium signals}

Calcium signals are indispensable for proper functioning of keratinocytes and abnormalities in calcium homeostasis have been shown to lead skin disorders [25]. In order to investigate whether Cx26-D50A and A88V mutations cause any change in the internal calcium levels, we determined cellular calcium content by a calcium indicator Fluo-3AM using flow cytometry (Figure 3). Comparison of Fluo-3AM signals among groups suggested that calcium amount in cells with Cx26-WT and cells transfected with the negative control, pCS2+ were similar $(p=0.12)$. However, cells with 
A
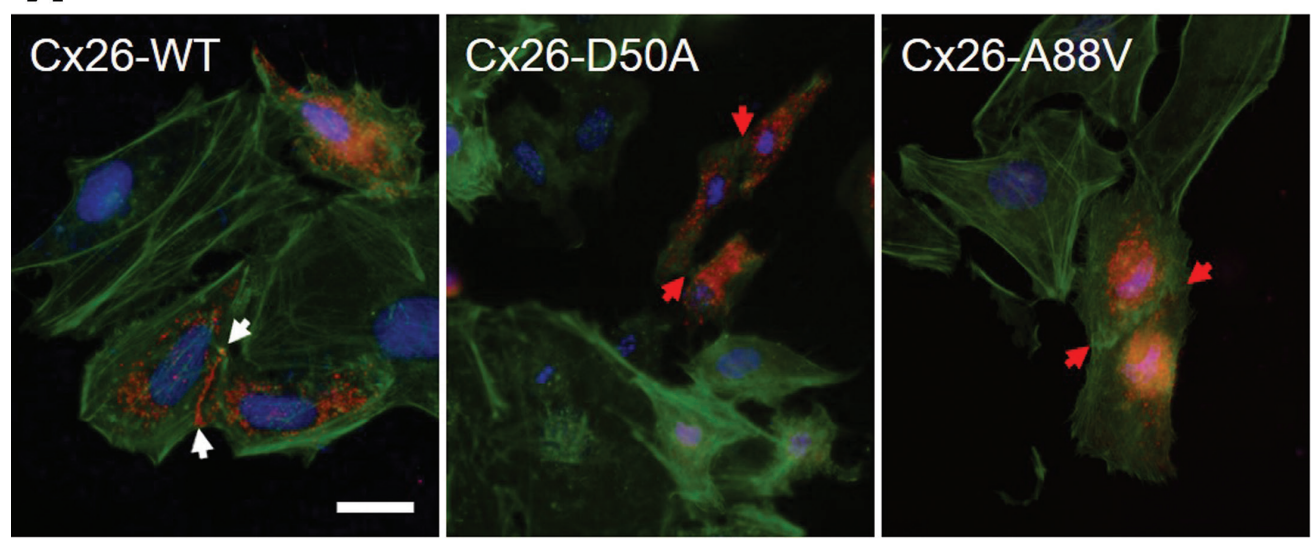

B
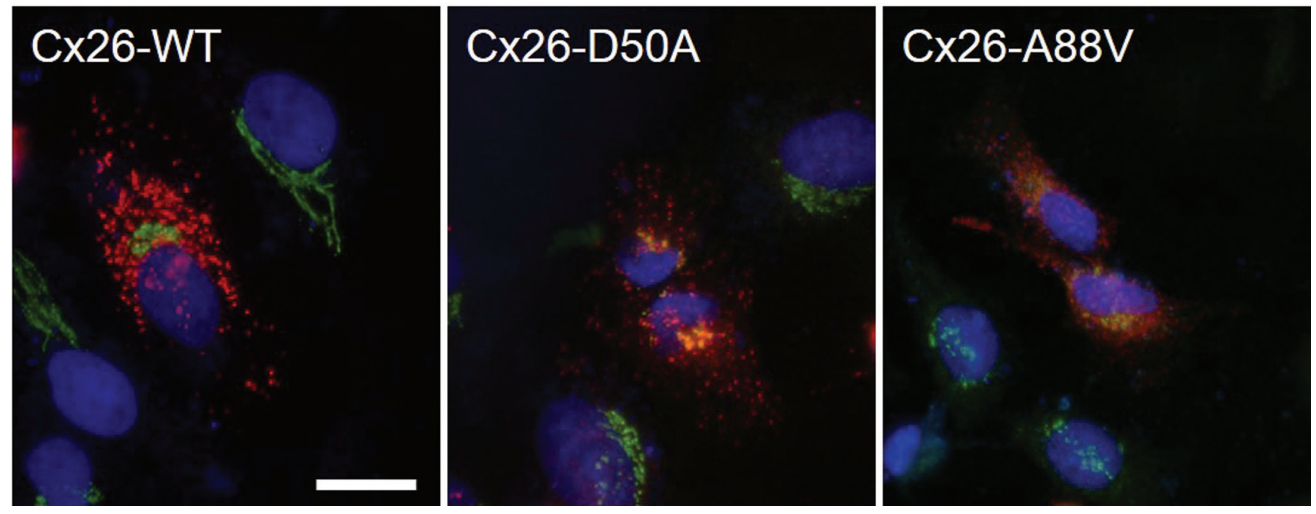

Figure 2: Comparison of $\mathrm{C} \times 26-\mathrm{WT}, \mathrm{D} 50 \mathrm{~A}$ and A88V localization and trafficking in gap junctional communication deficient HeLa cells.

(A) Cx26-WT, D50A and A88V transfected HeLa cells were co-stained with phalloidin for actin (green) and Cx26 antibody (red). Blue is DAPI staining of the nucleus. White arrows point out the gap junction plaques between Cx26-WT cells and red arrows show cell-cell contact sites of cells transfected with Cx26-D50A and A88V. Cells with only green and blue signals indicate untransfected cells. Scale bar $20 \mu \mathrm{m}$. (B) Cx26-WT, D50A and A88V transfected cells were co-stained with Cx26 (red) and the Golgi apparatus marker, golgin-97 (green) antibodies. Blue shows DAPI staining of the nucleus. Yellow signals in Cx26-D50A and Cx26-A88V point out the co-localization of Cx26 and golgin-97. Scale bar $20 \mu \mathrm{m}$.

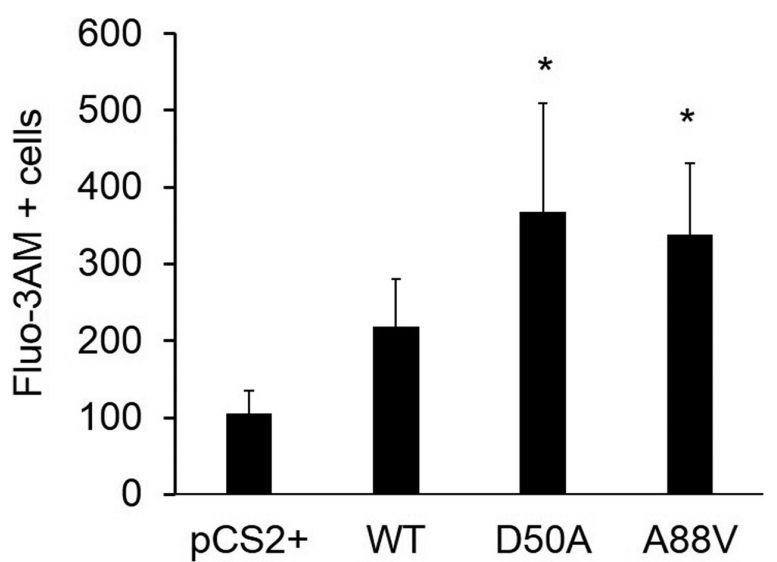

Figure 3: Effect of Cx26-D50A and A88V hemichannels on intracellular calcium levels.

Intracellular calcium content was compared among mutants, Cx26-WT and pCS2+ containing cells ( $p$-value * $<0.05)$.
Cx26-D50A and A88V had 1.6-fold increase in the intracellular calcium amount with respect to Cx26-WT cells $(p=0.04)$ (Figure 3). These changes in calcium content suggested that Cx26-D50A and A88V mutations interfered with calcium mechanisms in these cells.

\section{Discussion}

KID syndrome is a rare congenital disorder associated with dominant Cx26 mutations. The molecular mechanisms leading to KID syndrome skin phenotypes is not exactly known and in vitro characterization of $\mathrm{Cx} 26$ mutations has helped to understand the effect of mutations on cell homeostasis and hence the generation of skin anomalies in affected individuals. Here, we characterized 
the properties of KID syndrome associated Cx26-D50A and $\mathrm{A} 88 \mathrm{~V}$ mutations, which were shown to form aberrant hemichannels by electrophysiological analysis [26]. D50A and A88V mutations resulted in an increase in the uptake of neurobiotin into cells from the extracellular environment, implicating the ability of mutant hemichannels to transfer larger molecules than small ions into cells. Moreover, these mutations prevented the formation of gap junction channels at the cell-to-cell junctions and a fraction of mutant proteins were observed to be retained in the Golgi apparatus compared to Cx26-WT. Finally, mutations caused an elevation in the intracellular calcium levels in cells containing D50A and A88V compared to cells with Cx26-WT. These results confirmed the activities of leaky hemichannels due to Cx26-D50A and A88V mutations and may also implicate the involvement of altered protein trafficking and elevated intracellular calcium content due to aberrant hemichannels in KID syndrome.

Cx26 mutations cause both non-syndromic and syndromic deafness. In vitro characterization of mutations leading to non-syndromic deafness suggested these mutations are loss-of-function mutations and they only affect the cochlear function but have no effect on other Cx26 expressing tissues such as the skin and the liver [15, 29-31]. On the other hand, Cx26 mutations associated with syndromic deafness were shown to result in the acquisition of novel functions which influence the homeostasis of both the inner ear and the skin and are considered as gain of function mutations [14, 32, 33]. For example, Cx26 mutations linked to KID syndrome were shown to form aberrant hemichannels and activities of abnormal hemichannels are suggested to be the main mechanisms underlying skin pathologies [22, 26, 33, 34]. The molecular mechanisms related to this phenotype might be the uncontrolled release of signaling molecules including ATP into the extracellular environment through aberrant Cx26 hemichannels and therefore the disruption of calcium signaling. Changes in calcium homeostasis can affect different cellular processes including proliferation, differentiation and survival that can contribute to the development of epidermal abnormalities $[25,35]$. Here, we showed that expression of Cx26-D50A and $\mathrm{A} 88 \mathrm{~V}$ mutations in mammalian cells resulted in an increase in the intracellular calcium content which may suggest the contribution of altered calcium homeostasis that might contribute to the development of epidermal phenotypes.

Cx26-D50A and A88V mutations prevented the formation of gap junction plaques at cell-to-cell communication sites. The observation of aberrant hemichannel activities suggest the transport of connexons to the plasma membrane where they formed non-junctional hemichannels. However, these hemichannels were not able to dock with each other to complete the formation of gap junction channels on the plasma membrane. Furthermore, a fraction of Cx26-D50A and A88V mutant proteins were observed to accumulate in the Golgi apparatus, suggesting defects in Cx26 trafficking. Cx26 proteins were shown to be transported to the plasma membrane either passing through the Golgi apparatus or by bypassing the Golgi apparatus depending on the cell type, suggesting different membrane transport pathways for Cx26 [36, 37]. Further, Cx26-D66H mutation associated with Vohwinkel syndrome and R184Q mutation linked to dominant hearing loss were also shown to be retained in the Golgi apparatus [38, 39]. These mutations might impair the folding of the proteins, resulting in their accumulation in the Golgi apparatus that may play role in the generation of stress responses to influence cellular processes [40]. Thus, both the leaky hemichannel activity and retaining of mutant proteins in the Golgi apparatus can alter cellular physiology.

In conclusion, characterization of $\mathrm{Cx} 26$ mutations provide an invaluable tool in the elucidation of molecular mechanisms underlying the KID syndrome. It will help us to expand our understanding of the disorders, the role of Cx26 in epidermal homeostasis and also our ability to develop new therapeutic approaches for patients.

Acknowledgments: We thank Thomas W. White from Stony Brook University, NY, USA for kindly providing pIRES2EGFP2, pCS2+ and pBSBK-Cx26WT vectors. Expert technical help from Drs. Ozden Yalcin-Ozuysal, Engin Ozcivici and Izmir Institute of Technology, Biotechnology and Bioengineering Research and Application Center is well appreciated. This work was supported by The Scientific and Technological Research Council of Turkey Grant (210T035) and FP7 Marie Curie Re-Integration Grant (PIRG08-GA-2010-277101).

Conflict of interest: Authors have no conflicts of interest.

\section{References}

1. Oyamada M, Oyamada Y, Takamatsu T. Regulation of connexin expression. Biochim Biophys Acta 2005;1719:6-23.

2. Churko JM, Laird DW. Gap junction remodeling in skin repair following wounding and disease. Physiology (Bethesda) 2013;28:190-8.

3. White TW, Paul DL. Genetic diseases and gene knockouts reveal diverse connexin functions. Annu Rev Physiol 1999;61:283-310. 
4. Valiunas V, Polosina YY, Miller H, Potapova IA, Valiuniene L, Doronin S, et al. Connexin-specific cell-to-cell transfer of short interfering RNA by gap junctions. J Physiol 2005;568(Pt 2):459-68.

5. Slavi N, Rubinos C, Li L, Sellitto C, White TW, Mathias R, et al. Connexin 46 (cx46) gap junctions provide a pathway for the delivery of glutathione to the lens nucleus. J Biol Chem 2014;289:32694-702.

6. Wang N, De Bock M, Decrock E, Bol M, Gadicherla A, Vinken M, et al. Paracrine signaling through plasma membrane hemichannels. Biochim Biophys Acta 2013;1828:35-50.

7. Valiunas V. Biophysical properties of connexin-45 gap junction hemichannels studied in vertebrate cells. J Gen Physiol 2002;119:147-64.

8. Bukauskas FF, Kreuzberg MM, Rackauskas M, Bukauskiene A, Bennett MV, Verselis VK, et al. Properties of mouse connexin 30.2 and human connexin 31.9 hemichannels: implications for atrioventricular conduction in the heart. Proc Natl Acad Sci USA 2006;103:9726-31.

9. Gonzalez D, Gomez-Hernandez JM, Barrio LC. Species specificity of mammalian connexin-26 to form open voltage-gated hemichannels. FASEB J 2006;20:2329-38.

10. Contreras JE, Sanchez HA, Eugenin EA, Speidel D, Theis M, Willecke K, et al. Metabolic inhibition induces opening of unapposed connexin 43 gap junction hemichannels and reduces gap junctional communication in cortical astrocytes in culture. Proc Natl Acad Sci USA 2002;99:495-500.

11. Anselmi F, Hernandez VH, Crispino G, Seydel A, Ortolano S, Roper SD, et al. ATP release through connexin hemichannels and gap junction transfer of second messengers propagate $\mathrm{Ca} 2+$ signals across the inner ear. Proc Natl Acad Sci USA 2008;105:18770-5.

12. Robertson J, Lang S, Lambert PA, Martin PE. Peptidoglycan derived from Staphylococcus epidermidis induces Connexin43 hemichannel activity with consequences on the innate immune response in endothelial cells. Biochem J 2010;432:133-43.

13. Montgomery JR, White TW, Martin BL, Turner ML, Holland SM. A novel connexin 26 gene mutation associated with features of the keratitis-ichthyosis-deafness syndrome and the follicular occlusion triad. J Am Acad Dermatol 2004;51:377-82.

14. Gerido DA, Derosa AM, Richard G, White TW. Aberrant hemichannel properties of $\mathrm{Cx} 26$ mutations causing skin disease and deafness. Am J Physiol Cell Physiol 2007;293:C337-45.

15. Mese G, Valiunas V, Brink PR, White TW. Connexin26 deafness associated mutations show altered permeability to large cationic molecules. Am J Physiol Cell Physiol 2008;295:C966-74.

16. Kelsell DP, Dunlop J, Stevens HP, Lench NJ, Liang JN, Parry G, et al. Connexin 26 mutations in hereditary non-syndromic sensorineural deafness. Nature 1997;387:80-3.

17. Richard G, Rouan F, Willoughby CE, Brown N, Chung P, Ryynänen $M$, et al. Missense mutations in GJB2 encoding connexin-26 cause the ectodermal dysplasia keratitis-ichthyosis-deafness syndrome. Am J Hum Genet 2002;70:1341-48.

18. Pfenniger A, Wohlwend A, Kwak BR. Mutations in connexin genes and disease. Eur J Clin Invest 2011;41:103-16.

19. Mese G, Richard G, White TW. Gap junctions: basic structure and function. J Invest Dermatol 2007;127:2516-24.

20. Kelly JJ, Simek J, Laird DW. Mechanisms linking connexin mutations to human diseases. Cell Tissue Res 2015;360:701-21.
21. Lee JR, Derosa AM, White TW. Connexin mutations causing skin disease and deafness increase hemichannel activity and cell death when expressed in Xenopus oocytes. J Invest Dermatol 2009;129:870-78.

22. Garcia IE, Maripillan J, Jara O, Ceriani R, Palacios-Munoz A, Ramachandran J, et al. Keratitis-ichthyosis-deafness syndromeassociated Cx26 mutants produce nonfunctional gap junctions but hyperactive hemichannels when co-expressed with wild type Cx43. J Invest Dermatol 2015;135:1338-47.

23. Terrinoni A, Codispoti A, Serra V, Didona B, Bruno E, Nisticò R, et al. Connexin 26 (GJB2) mutations, causing KID Syndrome, are associated with cell death due to calcium gating deregulation. Biochem Biophys Res Commun 2010;394:909-14.

24. Denda M, Hosoi J, Asida Y. Visual imaging of ion distribution in human epidermis. Biochem Biophys Res Commun 2000;272:134-7.

25. Savignac M, Edir A, Simon M, Hovnanian A. Darier disease: a disease model of impaired calcium homeostasis in the skin. Biochim Biophys Acta 2011;1813:1111-7.

26. Mhaske PV, Levit NA, Li L, Wang HZ, Lee JR, Shuja Z, et al. The human Cx26-D50A and Cx26-A88V mutations causing keratitisichthyosis-deafness syndrome display increased hemichannel activity. Am J Physiol Cell Physiol 2013;304:C1150-8.

27. Demiray L, Ozcivici E. Bone marrow stem cells adapt to lowmagnitude vibrations by altering their cytoskeleton during quiescence and osteogenesis. Turkish J Biol 2015;39:88-97.

28. Caro AA, Cederbaum Al. Role of calcium and calcium-activated proteases in CYP2E1-dependent toxicity in HEPG2 cells. J Biol Chem 2002;277:104-13.

29. Mese G, Londin E, Mui R, Brink PR, White TW. Altered gating properties of functional $C \times 26$ mutants associated with recessive non-syndromic hearing loss. Hum Genet 2004;115:191-9.

30. Zonta F, Buratto D, Cassini C, Bortolozzi M, Mammano F. Molecular dynamics simulations highlight structural and functional alterations in deafness-related M34T mutation of connexin 26. Front Physiol 2014;5:85.

31. Ambrosi C, Walker AE, Depriest AD, Cone AC, Lu C, Badger J, et al. Analysis of trafficking, stability and function of human connexin 26 gap junction channels with deafness-causing mutations in the fourth transmembrane helix. PLoS One 2013;8:e70916.

32. Rouan F, White TW, Brown N, Taylor AM, Lucke TW, Paul DL, et al. trans-dominant inhibition of connexin- 43 by mutant connexin-26: implications for dominant connexin disorders affecting epidermal differentiation. J Cell Sci 2001;114(Pt 11):2105-13.

33. Lee JR, White TW. Connexin-26 mutations in deafness and skin disease. Expert Rev Mol Med 2009;11:e35.

34. Levit NA, Mese G, Basaly MG, White TW. Pathological hemichannels associated with human $\mathrm{C} \times 26$ mutations causing Keratitis-Ichthyosis-Deafness syndrome. Biochim Biophys Acta 2012;1818:2014-9.

35. Menon GK, Elias PM, Feingold KR. Integrity of the permeability barrier is crucial for maintenance of the epidermal calcium gradient. Br J Dermatol 1994;130:139-47.

36. Martin PE, Blundell G, Ahmad S, Errington RJ, Evans WH. Multiple pathways in the trafficking and assembly of connexin 26,32 and 43 into gap junction intercellular communication channels. J Cell Sci 2001;114(Pt 21):3845-55.

37. Thomas T, Jordan K, Simek J, Shao Q, Jedeszko C, Walton P, et al. Mechanisms of $\mathrm{C} \times 43$ and $\mathrm{C} \times 26$ transport to the plasma 
membrane and gap junction regeneration. J.Cell Sci 2005; 118(Pt 19):4451-62.

38. Thomas T, Telford D, Laird DW. Functional domain mapping and selective trans-dominant effects exhibited by $\mathrm{Cx} 26$ disease-causing mutations. J Biol Chem 2004;279: 19157-68.
39. Su CC, Li SY, Su MC, Chen WC, Yang JJ. Mutation R184Q of connexin 26 in hearing loss patients has a dominant-negative effect on connexin 26 and connexin 30. Eur J Hum Genet 2010;18:1061-4.

40. Hicks SW, Machamer CE. Golgi structure in stress sensing and apoptosis. Biochim Biophys Acta 2005;1744:406-14. 